\title{
UJI AKTIVITAS SITOTOKSIK EKSTRAK METANOL BUAH KETUMBAR (Coriandrum sativum Linn) TERHADAP ARTEMIA SALINA LEACH DENGAN UJI BSLT (Brine Shrimp Lethality Test)
}

\author{
Mega Yulia ${ }^{1}$, Rani Anggraini ${ }^{2}$, Farizal $^{3}$ \\ 1,2,3 Akademi Farmasi Imam Bonjol \\ Email korespondensi: megayuriano@yahoo.com.sg
}

\begin{abstract}
ABSTRAK
Buah ketumbar merupakan tanaman herbal yang dapat dimanfaatkan sebagai obat tradisional. Salah satu manfaat yang diharapkan oleh masyarakat dari buah ketumbar adalah sebagai obat anti kanker. Penelitian ini bertujuan untuk mengetahui aktivitas sitotoksik ekstrak buah ketumbar (Coriandrum sativum Linn) terhadap larva udang (Artemia salina Leach) dengan metode BSLT (Brine Shrimp Lethality Test). Buah ketumbar diekstrak dengan menggunakan pelarut metanol dan metoda maserasi kemudian dipekatkan dengan rotary evaporator hingga didapatkan ekstrak kental. Pengujian aktivitas sitotoksik menggunakan ekstrak metanol dengan konsentrasi larutan uji $1.000 \mathrm{ppm}, 100 \mathrm{ppm}, 10 \mathrm{ppm}$ dan $1 \mathrm{ppm}$. Dari uji aktivitas sitotoksik dapat diketahui bahwa ekstrak metanol buah ketumbar memiliki aktivitas sitotoksik dengan nilai $\mathrm{LC}_{50}$ sebesar $32,35 \mathrm{ppm}$.
\end{abstract}

Kata kunci : Ketumbar, Coriandrum sativum, Sitotoksik, BSLT 


\title{
CYTOTOXIC ACTIVITIES OFMETHANOL EXTRACT OF CORIANDER (Coriandrum sativum Linn) FRUITS USING BRINE SHRIMP LETHALITY TEST
}

\begin{abstract}
Coriander is a common herb can be used as traditional medicine. One of the expected benefits of Coriander fruits is an anti-cancer. This study aims to determine the cytotoxic activity of Coriander extract (Coriandrum sativum Linn) on shrimp larvae (Artemia salina Leach) with the BSLT (Brine Shrimp Lethality Test) method. Coriander fruits was extracted using methanol solvent and maceration method, then concentrated it with a rotary evaporator until a thick extract. Cytotoxic activity test used methanol extract with several concentration : 1,000 ppm, 100 ppm, $10 \mathrm{ppm}$, and $1 \mathrm{ppm}$. The result of this research reveal that methanol extract of Coriander fruits has cytotoxic activity with $L_{50}$ value is 32.35 ppm.
\end{abstract}

Keywords : Coriander, Coriandrum sativum, Cytotoxic, BSLT

\section{PENDAHULUAN}

Kanker merupakan penyakit yang tidak diketahui penyebabnya secara pasti, tetapi dipengaruhi oleh banyak faktor seperti merokok atau

terkena paparan asap rokok, mengkonsumsi alkohol, obesitas, diet tidak sehat, kurang aktifitas fisik dan infeksi (Sudiana, 2008). Pengobatan terhadap kanker dapat dilakukan melalui operasi, radiasi, atau dengan memberikan kemoterapi (Majeed W, 2014). Minat terhadap penggunaan obat tradisional khususnya untuk penyakit kanker akhir-akhir ini cenderung meningkat. Kecenderungan tersebut

kemungkinan disebabkan adanya kekhawatiran akan efek samping yang ditimbulkan oleh obat-obatan modern dan juga dengan alasan obat tradisional mudah didapat dan harganya murah (Sudewo, 2012).
Penggunaan tanaman obat sudah dikenal sejak lama oleh masyarakat dunia, termasuk Indonesia (Suparni \& Wulandari, 2012). Dari 30.000 spesies tumbuhan yang ada, lebih kurang 1.260 spesies dapat dimanfaatkan sebagai obat, salah satunya sebagai obat kanker (Mangan, 2010). Pengobatan kanker yang relatif mahal dan adanya efek samping yang merugikan dari obat-obat kimia menyebabkan masyarakat mulai mencari pengobatan alternatif dengan obat-obatan tradisional, termasuk tumbuh-tumbuhan yang memungkinkan untuk mendapatkan kesembuhan. WHO

(World Health Organization) merekomendasikan penggunaan obat tradisional termasuk herbal dalam pemeliharaan kesehatan masyarakat, pencegahan dan pengobatan penyakit, terutama untuk penyakit kronis, penyakit degeneratif dan kanker (Faridah, 2012). 
Ketumbar (Coriandrum sativum L.) merupakan salah satu tanaman yang dimanfaatkan sebagai obat oleh masyarakat.Ketumbar secara tradisional telah digunakan sebagai stimulan, karminatif, antispasmodik, diuretik dan anti-rematik, antiemetik juga berpotensi sebagai antioksidan. Selain itu secara invitro bersifat antibakteri dan anti jamur. Skrining fitokimia ketumbar diketahui mengandung karbohidrat, protein, senyawa fenolik, tanin, dan flavonoid (Melo et al, 2004; Rajeswari \& Bondada, 2011; Tianandari \& Rasidah, 2017).

\section{METODE PENELITIAN}

\section{A. Alat dan Bahan}

1. Alat

Alat yang digunakan pada penelitian ini adalah lumpang, stamfer, pipet tetes, tabung reaksi, rak tabung reaksi, plat tetes, penjepit tabung reaksi, lampu spritus, korek api, pisau, papan landasan, timbangan, botol gelap, gelas piala $500 \mathrm{ml}$, erlemeyer, corong, batang pengaduk, satu set alat rotary evaporator, vial, timbangan analitik, desikator, aquarium, aerator, lampu 5 watt.

\section{Bahan}

Bahan yang digunakan $\mathrm{H}_{2} \mathrm{SO}_{4}$ $2 \mathrm{~N}$, serbuk logam $\mathrm{Mg}, \mathrm{HCl}$ pekat, anhidrat asetat, $\mathrm{FeCl}_{3}$, pereaksi Mayer, pereaksi Liebermann-Burchard, pereaksi Dragendorff, kloroform, amoniak, metanol, kapas, kertas saring, air laut, buah ketumbar, aluminium foil, Dimetil Sulfoksida (DMSO). Sedangkan hewan uji yang digunakan adalah larva udang (Artemia salina Leach).

\section{B. Cara Kerja \\ 1. Pengambilan sampel}

Sampel yang digunakan adalah buah ketumbar (Coriandrum sativum Linn) yang dibeli di pasar Baso Kabupaten Agam sebanyak 150 gram.

\section{Proses ekstraksi}

Ekstraksi dilakukan dengan metoda maserasi dimana buah ketumbar yang telah ditumbuk timbang sebanyak 100 gram, kemudian masukkan ke dalam botol maserasi berwarna gelap, tambahkan metanol sampai buah

ketumbar terendam. Perendaman dilakukan selama 3 hari sambil diaduk sesekali guna mempercepat proses pelarutan komponen kimia yang terdapat dalam sampel. Ekstraksi dilakukan sebanyak $2 \mathrm{x}$ pengulangan dengan perlakuan yang sama. Sampel yang direndam dengan pelarut tadi disaring dengan menggunakan kertas saringan untuk mendapatkan maserat murni yang tidak ada pengotornya. Kemudian ekstrak dipekatkan dengan menggunakan rotary evaporator.

\section{Uji Skrining fitokimia}

\section{a. Alkaloid}

Sebanyak 2 gram sampel ditumbuk, gerus dalam lumpang dengan menambahkan sedikit pasir steril, tambahkan $10 \mathrm{ml}$ kloroform dan 5 tetes amoniak, gerus kembali. Larutan disaring kedalam tabung reaksi dan filtrat ditambahkan asam sulfat $2 \mathrm{~N}$ sebanyak 10 tetes. Filtrat dikocok dengan teratur kemudian dibiarkan beberapa lama sampai terbentuk dua lapisan. Lapisan asam dipindahkan diatas plat tetes sebanyak 6 tetes. Tiga tetes awal sebagai pembanding, sedangkan tiga tetes berikutnya masing- 
masing ditetesi pereaksi mayer dan wagner. Adanya alkaloid ditandai dengan terbentuknya endapan putih pada pereaksi mayer dan wagner.

\section{b. Steroid dan Terpenoid}

Lapisan kloroform pada pengujian alkaloid disaring menggunakan norit, lalu pindahkan kedalam tabung reaksi. Teteskan pada plat tetes dan dibiarkan mengering. Setelah mengering ditambahkan asam asetat anhidratdan asam sulfat pekat. Terbentuk warna merah menunjukkan positif terpenoid, sedangkan warna biru menunjukkan positif steroid.

\section{c. Flavonoid}

Sebanyak 2 gram sampel yang telah ditumbuh masukkan kedalam tabung reaksi, lalu tambahkan $5 \mathrm{ml}$ etanol dan dipanaskan selama lima menit. Teteskan pada plat tetes sebanyak 2 tetes, tetes pertama ditambah beberapa tetes $\mathrm{HCl}$ pekat dan 0,2 gram serbuk $\mathrm{Mg}$. Hasil positif ditunjukkan dengan timbulnya warna merah tua dalam waktu 3 menit.

Sedangkan tetes kedua untuk pemeriksaan fenolik dengan menambahkan $\mathrm{FeCl}_{3}$. Dimana warna biru atau biru ungu memberikan indikasi positif fenolik.

\section{d. Saponin}

Pemeriksaan saponin dapat dilakukan dengan larutan sisapemanasan pada pemeriksaan flavonoid sebelumnya, masukkan ke tabung reaksi dan dikocok beberapa saat dan bila terbentuk busa permanen lebih kurang 5 menit, maka positif mengandung saponin (Anonim, 1977).

\section{Penetasan telur Artemia salina Leach}

Siapkan wadah untuk penetasan telur udang. Wadah yang digunakan dibagi menjadi dua bagian, bagian gelap dan terang kemudian dimasukkan air laut. Satu ruang dalam wadah tersebut diberi penerangan dengan cahaya lampu untuk membantu proses penetasan, sedangkan ruangan sebelahnya ditutup dengan aluminium atau lakban hitam. Lalu telur Artemia salina Leach direndam pada bagian yang gelap, dan biarkan selama 24 jam.

\section{Pembuatan larutan uji dan pengujian sitotoksik}

Larutan uji dibuat dengan konsentrasi 1000, 100, 10 dan 1 ppm. Pembuatan konsentrasi diawali dengan membuat larutan induk dengan konsentrasi 10.000 ppm sebanyak $10 \mathrm{ml}$ dengan cara menimbang $100 \mathrm{mg}$ ekstrak kemudian dilarutkan dengan metanol ad

10 ml. Kemudian dilakukan pengenceran bertingkat sehingga didapatkan konsentrasi 1000, 100, 10 dan 1 ppm. Untuk larutan kontrol digunakan metanol $1 \mathrm{ml}$ dimasukan dalam vial dan diberi label kontrol. Kemudian semua vial larutan uji dan kontrol dimasukan ke dalam oven dengan suhu $60^{\circ} \mathrm{C}$ selama 2 jam atau hingga ekstrak kering.Keluarkan larutan uji dan kontrol setelah kering ( \pm 2 jam) dioven. Kemudian tambahkan 2 tetes Dimethil Sulfoxid (DMSO) ke dalam masing-masing vial aduk ad homogen, tambahkan tiap-tiap vial $\pm 4 \mathrm{ml}$ air laut, dan masukan 10 ekor larva udang Artemia salina Leach yang berumur 24 
jam ke dalam vial dan tambahkan air laut ad $10 \mathrm{ml}$. Vial-vial tersebut diletakan dibawah penerangan selama 24 jam.Amati jumlah larva udang Artemia salina Leach yang mati setelah
24 jam dalam tiap vial dan hitung nilai $\mathrm{LC}_{50}$ dengan menggunakan metode Farmakope Indonesia. Semua larutan uji dibuat rangkap 3 (tiga).

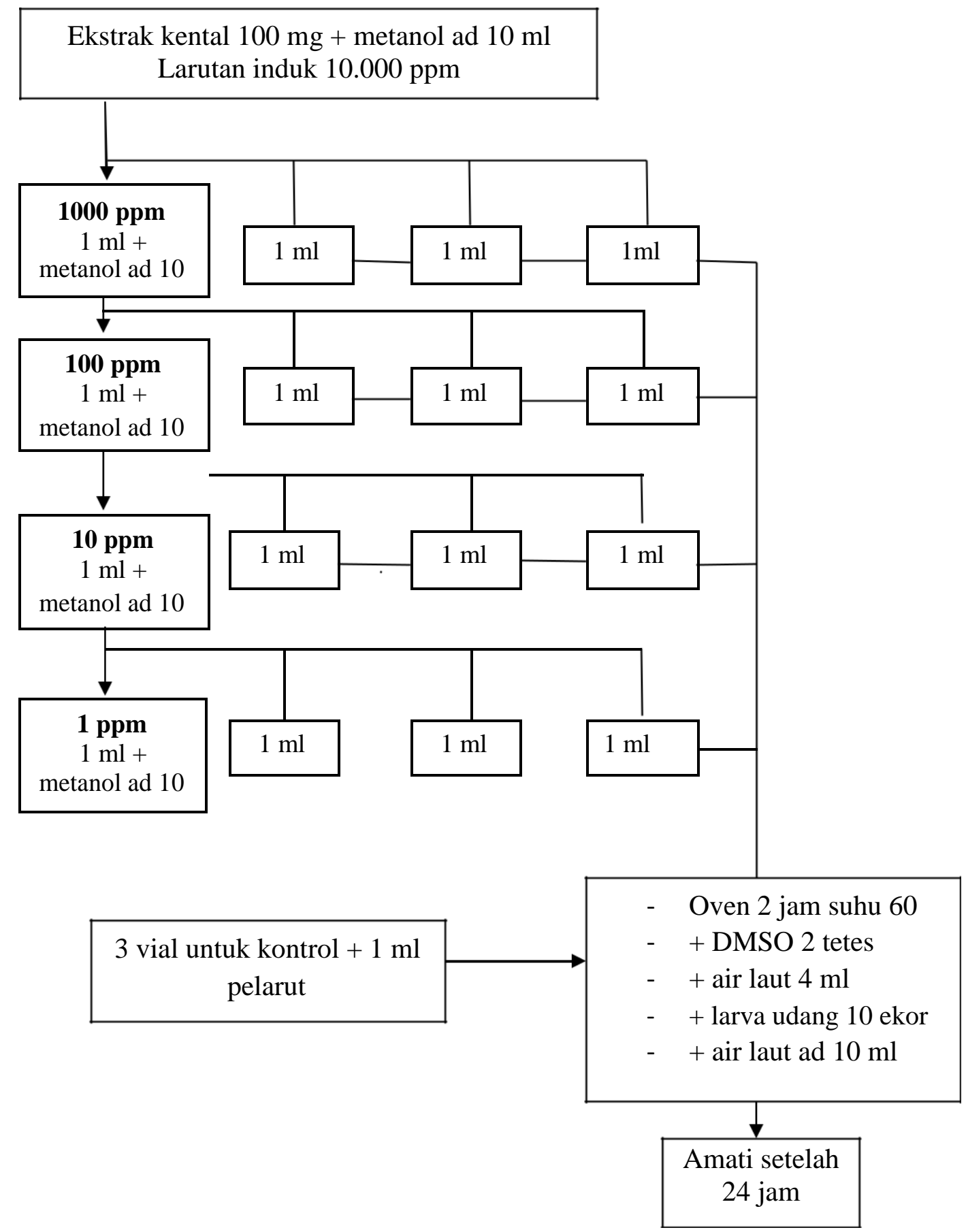

Gambar 1. Skema Kerja Pembuatan Konsentrasi dan Pengujian Aktivitas Sitotoksik Ekstrak metanol buah ketumbar (Coriandrum Sativum Linn) 


\section{Pengolahan data}

Perhitungan $\mathrm{LC}_{50}$ dengan jumlah hewan yang mati dibandingkan terhadap jumlah total hewan uji. Rumus yang digunakan adalah rumus Pehitungan $\mathrm{LC}_{50}$ berdasarkan Farmakope Indonesia Edisi III, yaitu :

$\mathrm{M}=\mathrm{a}-\mathrm{b}(\Sigma \mathrm{pi}-0,5)$

\section{HASIL DAN PEMBAHASAN}

Dari 100 mg buah ketumbar yang diekstrak menggunakan pelarut metanol dengan metoda maserasi dan dikentalkan dengan rotary evaporator didapatkan berat ekstrak kental buah ketumbar sebesar 3,73 gram.Metode maserasi dipilih karena alat dan cara yang digunakan sangat sederhana, dapat digunakan untuk sampel yang tahan terhadap pemanasan maupun tidak tahan pemanasan. Pelarut yang digunakan untuk maserasi adalah metanol karena pelarut ini bersifat universal, dan juga dapat menghalangi pertumbuhan sebagian besar bakteri sehingga dapat berguna sebagai pengawet (Syamsuni, 2007). Sampel direndam dalam wadah botol gelap untuk melindungi senyawa yang dapat rusak oleh cahaya (Djamal, 2010).

Maserat dipekatkan dengan menggunakan rotary evaporator. Prinsip alat ini pemisahan menggunakan panas, putaran, dan tekanan yang lebih rendah sehingga memungkinkan pelarut mendidih pada titik didih yang lebih rendah, penguapan yang lebih cepat dan zat yang terkandung didalam pelarut tidak rusak oleh suhu tinggi (Anonim, 2008).

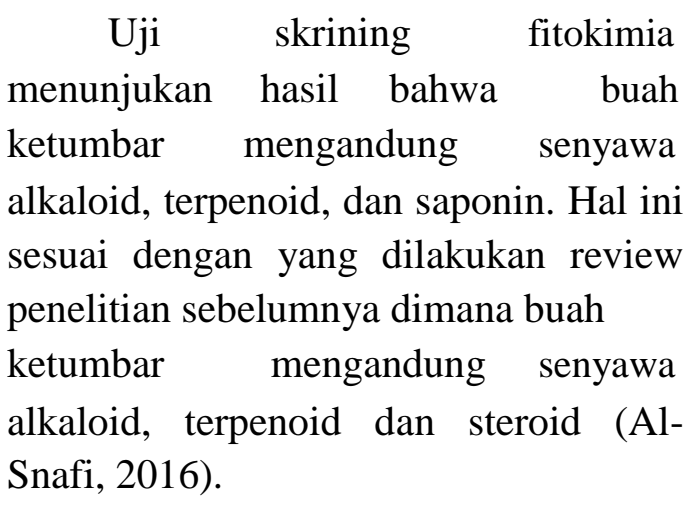

Tabel 1. Uji skrining Fitokimia dari buah ketumbar (Coriandrum Sativum Linn)

\begin{tabular}{ccc}
\hline Kandungan senyawa & Pereaksi & Hasil \\
\hline Alkaloid & Mayer & + \\
Saponin & Asam klorida & + \\
Flavonoid & $\begin{array}{c}\text { Asam klorida, serbuk } \\
\text { magnesium }\end{array}$ & - \\
Fenolik & $\mathrm{FeCl}_{3}$ & - \\
Terpenoid & Anhidrat asetat & + \\
Steroid & Anhidrat asetat & - \\
\hline
\end{tabular}


Untuk pengujian sitotoksik atau LC $_{50}$ digunakan metode Brine Shrimp Lethality Test (BSLT). Metode ini digunakan karena mudah dan cepat, juga karena perkembangan larva mirip dengan perkembangan sel kanker yang cepat dan merupakan salah satu metode uji toksisitas yang banyak digunakan dalam penelusuran senyawa bioaktif yang bersifat toksik dari bahan alam. Metode ini menggunakan larva udang Artemia salina Leach sebagai hewan uji (Radji, 2008). Penetasan larva udang dilakukan dengan cara merendam telur udang dengan air laut didalam aquarium dan dilengkapi dengan aerator dan lampu 5 watt. Penggunaan aerator untuk memberikan oksigen dari gelembung udara yang dihasilkan, sedangkan penggunaan lampu 5 watt sebagai sumber cahaya yang akan dicari oleh larva udang yang telah menetas.

Konsentrasi yang digunakan dalam pengujian $\mathrm{LC}_{50}$ adalah 1.000 ppm, 100 ppm, 10 ppm dan 1 ppm. Semua larutan uji yang telah dibuat dimasukkan kedalam oven selama 2 jam pada suhu $60^{\circ} \mathrm{C}$, larutan uji tersebut dimasukkan kedalam oven untuk menguapkan metanol sehingga yang tinggal hanya ekstrak kental. Setelah itu masing-masing larutan uji dikeluarkan dari dalam oven dan ditambahkan 2 tetes DMSO dan diaduk. Penambahan DMSO bertujuan untuk menambah kelarutan ekstrak dan tidak bersifat toksik.Kemudian amati dan hitung larva udang yang mati setelah 24 jam penyimpanan dibawah penerangan.Pada pengujian ini juga dilakukan pengujian menggunakan larutan kontrol yang tidak ditambahkan dengan ekstrak. Tujuannya untuk memastikan kematian pada hewan uji disebabkan oleh ekstrak yang diberikan, bukan karena pelarut, air laut ataupun DMSO.

Dari pengujian $\mathrm{LC}_{50}$ didapatkan hasil bahwa dari 10 ekor hewan percobaan pada kontrol memiliki ratarata kematian 0 ekor hewan percobaan. Hal ini menunjukan bahwa larutan kontrol tidak memberikan efek kematian terhadap larva udang. Kematian untuk larutan uji 1.000 ppm memiliki rata-rata kematian 10 ekor hewan uji, pada larutan uji 100 ppm memiliki rata-rata kematian 7,3 hewan uji, pada larutan uji 10 ppm memiliki rata-rata kematian 2,3 hewan uji, pada larutan uji 1 ppm memiliki rata-rata kematian 0,3 hewan uji.

Tabel 2. Hasil Uji Aktivitas Ekstrak Metanol Buah Ketumbar

\begin{tabular}{lcccc}
\hline $\begin{array}{c}\text { Konsentrasi Ekstrak } \\
\text { Daun Sirsak }\end{array}$ & \begin{tabular}{c} 
Jumlah Hewan \\
\cline { 2 - 3 }
\end{tabular} & $\begin{array}{c}\text { Total Kematian } \\
\text { Hewan Uji }\end{array}$ & $\begin{array}{c}\text { Rata- } \\
\text { rata }\end{array}$ \\
\hline \multirow{2}{*}{ Kontrol } & 10 & 0 & & 0 \\
& 10 & 0 & 0 & 0 \\
& 10 & 0 & &
\end{tabular}




\begin{tabular}{|c|c|c|c|c|}
\hline \multirow{3}{*}{$1000 \mathrm{ppm}(10 \mathrm{ml})$} & 10 & 10 & \multirow{3}{*}{30} & \multirow[b]{2}{*}{10} \\
\hline & 10 & 10 & & \\
\hline & 10 & 10 & & \\
\hline \multirow{3}{*}{$100 \mathrm{ppm}(10 \mathrm{ml})$} & 10 & 7 & \multirow{3}{*}{22} & \multirow{3}{*}{7,3} \\
\hline & 10 & 6 & & \\
\hline & 10 & 9 & & \\
\hline \multirow{3}{*}{10 ppm $(10 \mathrm{ml})$} & 10 & 2 & \multirow{3}{*}{7} & \multirow{3}{*}{2,3} \\
\hline & 10 & 3 & & \\
\hline & 10 & 2 & & \\
\hline \multirow{3}{*}{$1 \mathrm{ppm}(10 \mathrm{ml})$} & 10 & 0 & \multirow{3}{*}{1} & \multirow{3}{*}{0,3} \\
\hline & 10 & 1 & & \\
\hline & 10 & 0 & & \\
\hline
\end{tabular}

Dari pengujian tersebut, data diolah menggunakan rumus penentuan LC $_{50}$ yang ada di Farmakope Indonesia dapat diketahui bahwa ekstrak metanol buah ketumbar memberikan aktivitas sitotoksik dengan $\mathrm{LC}_{50}$ sebesar 32,35 ppm. Hal ini juga sebanding dengan penelitian sebelumnya menggunakan pelarut etanol, diketahui bahwa ekstrak etanol buah ketumbar memberikan aktivitas sitotoksik dengan $\mathrm{LC}_{50}$ sebesar 40,548 ppm (Tianandari \& Rasidah, 2017) . Dari data diatas dapat disimpulkan bahwa nilai tersebut

menunjukkan adanya aktivitas sitotoksik karena ekstrak dinyatakan aktif apabila memiliki nilai $\mathrm{LC}_{50}$ lebih kecil dari $1000 \mu \mathrm{g} / \mathrm{ml}$ (Harmita \& Radji, 2008). Dari hasil penelitian ekstrak etanol buah ketumbar ini memiliki kandungan senyawa metabolit sekunder yaitu alkaloid, flavonoid dan saponin. Berdasarkan studi literatur, senyawa metabolit sekunder alkaloid, flavonoid dan saponin yang dihasilkan dari beberapa tanaman mempunyai peranan signifikan dalam menghambat aktivitas protein, enzim dan persinyalan sel dari sel kanker (Iqbal J, et al., 2017). Seperti hasil penelitian Rampe tahun 2015 tentang aktivitas toksik dari jantung Pisang Kepok dengan metode BSLT terhadap larva udang Artemia salina memberikan nilai LC $_{50}$ sebesar 806 ppm (Rampe \& Joke, 2015). Daun Breynia cernua atau katuk hitam yang mengandung senyawa alkaloid, flavonoid, terpenoid dan tanin juga memiliki aktivitas sitotoksik dimana ekstrak etanol $96 \%$ yang diujikan dengan metode BSLT memiliki nilai LC $_{50}$ sebesar 255,87 ppm (Dirgantara, 2018). Ekstrak metanol daun soyogik yang mengandung senyawa flavonoid, fenolik dan tanin juga memiliki aktivitas sitotoksik dengan nilai $\mathrm{LC}_{50}$ sebesar 2,82 ppm untuk ekstrak etanol dan 12,59 untuk ekstrak etil asetat (Mojo, 2016).

\section{SIMPULAN}

Dari hasil uji Brine Shrimp Lethality Test terhadap ekstrak metanol buah ketumbar (Coriandrumsativum Linn) menunjukkan adanya aktivitas sitotoksik dengan nilai $\mathrm{LC}_{50}$ sebesar 32,35 ppm. Dari hasil penelitian ini 
buah ketumbar mempunyai efek sitotoksik dengan harga $\mathrm{LC}_{50}<1000$ ppm.

\section{UCAPAN TERIMAKASIH}

Terimakasih kami ucapkan kepada institusi kami tercinta Akademi Farmasi Imam Bonjol Bukittinggi atas terlaksananya penelitian ini.

\section{DAFTAR PUSTAKA}

Al-Snafi, A.E. (2016). A review of chemical constituens and pharmacological activities of Coriandrum Sativum. IOSR Journal Of Pharmacy, 6(7), 17-42.

Anonim.(2008). Parameter standar umum ekstrak tumbuhan obat, Cetakan 1. Departemen

Kesehatan RI, Jakarta.

Dirgantara S, Rosye HRT, Hendra KM, Edy M. (2018). Cytotoxic activity and phytochemical analysis of breynia cernua from Papua. Indonesian Journal of Pharmaceutical Science and Technology, 1(1), 31-36.

Djamal, R. (2010). Kimia bahan alam : prinsip-prinsip dasar isolasi dan identifikasi.Universitas Baiturrahma, Padang.

Faridah, I. (2012).Uji praskrinning aktivitas antikanker daun kembang bokor (Hydragea mamophylla) dengan metode
BSLT. Skripsi, Universitas Muhammadiyah Malang.

Harmita \& Radji M.(2008). Analisi hayati. Jakarta: Buku Kedokteran EGC.

Iqbal J, Banzeer AA, Tariq $\mathrm{M}$ et al. (2017). Plant-derived anticancer agents : A green anticancer approach. Asian Pacific Journal of Tropical

Biomedicine, 7(12): 11291150.

Majeed W, Bilal A, Ijaz Javed et al. (2014). Breast cancer major risk factors and recent development intreatment. Asian Pacific Journal of Cancer Prevention, 15, 33533358.

Mangan, Yellia.(2010). Sehat mencegah dan mengatasi kanker. Jakarta, Penerbit: Agromediapustaka.

Melo E A, Jorge MF \& Nonete BG. (2004). Characterization of antioxidant compounds in aqueous coriander extract (Coriandrum Sativum L.). Elsevier, Swiss Society Food Science and Technology, 38, 15-19.

Mojo T, Jemmy A, Max RJR. (2016). Kajian toksisitas dari fraksi heksana, etil asetat, dan etanol daun soyogik (Sauraia bracteosa DC). Jurnal MIPA UNSRAT online, 5(1), 40-43. 
Rajeshwari U \& Bondada A. (2011). Medicinal benefit of coriander (Coriander Sativum L). Saptula DD,1(1), 51-58.

Rampe MJ \& Joke LT. (2015). Pengujian fitokimia dan toksisitas ekstrak etanol jantung pisang kepok (Musa paradisiaca LINN.) dengan metode Brine Shrimp Lethality Test (BSLT). Jurnal Sainsmat, 136-147.

Suparni \& Wulandari. (2012). 1001 Ramuan tradisional asli Indonesia.Rapha Publishing, Yogyakarta.
Syamsuni H.A. (2007). Ilmu galenica. EGC, Jakarta.

Sudewo B.(2012). Basmi kanker dengan herbal.Jakarta : Visimedia.

Sudiana I K.(2008). Patologi molekul kanker. Jakarta: Salemba Medika.

Tianandari F\& Rasidah R. (2017).Uji stitotoksik ekstrak etanol buah ketumbar (Coriandrum Sativum Linn) terhadap artemia salina leach dengan metode BSLT. Action: Aceh Nutrition Journal, 2(2), 86-90. 